Review

\title{
Small but Smart: On the Diverse Role of Small Proteins in the Regulation of Cyanobacterial Metabolism
}

\author{
Fabian Brandenburg (D) and Stephan Klähn *(D) \\ Helmholtz Centre for Environmental Research_UFZ, 04318 Leipzig, Germany; fabian.brandenburg@ufz.de \\ * Correspondence: stephan.klaehn@ufz.de; Tel.: +49-341-235-4787
}

Received: 28 October 2020; Accepted: 26 November 2020; Published: 1 December 2020

\begin{abstract}
Over the past few decades, bioengineered cyanobacteria have become a major focus of research for the production of energy carriers and high value chemical compounds. Besides improvements in cultivation routines and reactor technology, the integral understanding of the regulation of metabolic fluxes is the key to designing production strains that are able to compete with established industrial processes. In cyanobacteria, many enzymes and metabolic pathways are regulated differently compared to other bacteria. For instance, while glutamine synthetase in proteobacteria is mainly regulated by covalent enzyme modifications, the same enzyme in cyanobacteria is controlled by the interaction with unique small proteins. Other prominent examples, such as the small protein CP12 which controls the Calvin-Benson cycle, indicate that the regulation of enzymes and/or pathways via the attachment of small proteins might be a widespread mechanism in cyanobacteria. Accordingly, this review highlights the diverse role of small proteins in the control of cyanobacterial metabolism, focusing on well-studied examples as well as those most recently described. Moreover, it will discuss their potential to implement metabolic engineering strategies in order to make cyanobacteria more definable for biotechnological applications.
\end{abstract}

Keywords: small proteins; metabolic regulation; biotechnology

\section{Introduction}

In nature, proteins are one of the most versatile classes of biological compounds. They serve multiple purposes as structural components, enzymes, membrane transporters, signaling molecules or regulatory factors. Given their tremendous variability in fulfilling tasks in all aspects of life, it is not surprising that proteins come in a manifold of sizes and shapes. For example, they can be single domain proteins or a part of huge protein complexes. The biggest so-far known example that is not part of a multiunit structure is the protein Titin, which is part of vertebrate muscles [1]. Depending on the splice variant, Titin has a size of 27,000-35,000 amino acids and contains over 300 domains [2]. On the contrary, the protein Tal, which was found in Drosophila melanogaster is composed of only 11 amino acids [3]. Albeit being so small, it is involved in controlling gene expression and tissue folding and hence, is the shortest functional protein described so far.

It is known that the mean protein length of bacteria is $40-60 \%$ shorter than of eukaryotes [4]. Moreover, it was found that up to $16 \%$ of all proteins in a prokaryotic organisms might be actually smaller than 100 amino acids [5]. Consequently, more and more studies are suggesting that likely hundreds of small proteins are synthesized in bacterial cells and serve important structural and regulatory functions [6]. Of course, some of these small proteins are known for decades and well-studied, such as, for example, thioredoxins, which play important roles as antioxidants in almost all organisms, not only prokaryotes [7-9]. However, genes encoding small proteins are likely to be overlooked even in modern 
genome annotations because the minimal cutoff for small open reading frames is typically set to 100 amino acids [10,11]. In turn, this indicates the existence of a whole, unexplored universe of small proteins to be discovered in bacteria, which is especially exemplified by the phylum of cyanobacteria.

Cyanobacteria are the only prokaryotes performing oxygenic photosynthesis. To conduct and maintain their complex photosynthetic machinery, which is composed of several functionally related protein complexes, cyanobacteria use a plethora of small proteins. Some examples like Psb27 have been shown to be important in photosystem II (PSII) repair [12], while others like PetP are involved in stress adaptation of the photosynthetic electron transport chain [13]. In fact, more than 10 proteins smaller than 50 amino acids have been characterized to be important for the function of PSII alone [14,15]. Additionally, 293 candidate-genes for proteins smaller than 80 amino acids have been identified in the cyanobacterial model organism Synechocystis sp. PCC 6803 (hereafter Synechocystis), indicating that cyanobacteria provide a paradigm for the utilization of small proteins and hence, the functional characterization of bacterial micro-proteomes [16].

This review highlights further prominent examples of small proteins in cyanobacteria beyond the photosynthetic apparatus, i.e., those exercising a regulatory function related to primary metabolism. However, in the literature, different definitions for the term 'small protein' exist. Some studies limit the term to proteins $\leq 85$ amino acids [17], while others also include proteins up to a size of 200 amino acids [18]. Some authors also use the term 'microproteins' which is typically defined as proteins up to a size of 80 amino acids [16]. In this review, we did not set a specific cut-off for the size of considered proteins, but focused on those candidates that regulate metabolic pathways via protein-protein interaction, among which various truly small proteins of only a few $\mathrm{kDa}$ are found. Finally, the potential of small proteins as an add-on for the currently existing molecular toolbox for metabolic engineering in cyanobacteria is discussed.

\section{Light Regulation of the Calvin-Benson Cycle by the Small Protein CP12}

In cyanobacteria, the Calvin-Benson cycle (CB) is the central pathway for the generation of biomass as it fixes $\mathrm{CO}_{2}$ by using energy (ATP) and reduction equivalents (NADPH) derived from the photosynthetic electron transport chain. In darkness however, cyanobacteria need to oxidize carbohydrates to cover their needs of ATP and reductive power. For a long time, it was believed that the Embden-Meyerhof-Parnas pathway (glycolysis) and the oxidative pentose phosphate pathway (OPP) are the only pathways for carbohydrate oxidation in cyanobacteria. Only quite recently it could be shown that the Entner-Doudoroff (ED) pathway is also active [19]. However, switching from a phototrophic to a heterotrophic mode cannot be achieved by simply activating the respective pathways. Both glycolysis and the OPP share several intermediates with the CB and thus may form a futile cycle when operated at the same time [19]. In order to prevent this, these pathways as well as the $\mathrm{CB}$ respond to several signals that trigger a regulation of their activities. For the $\mathrm{CB}$, these signals are thioredoxin, $\mathrm{pH}$, the levels of magnesium and certain metabolites such as fructose 6-phosphate and sedoheptulose 7-phosphate [20]. Some of these signals are transmitted into the regulation of enzyme activity by protein-protein interactions. In plants, the key enzyme of the $C B$, ribulose-1,5-bisphosphate-carboxylase/-oxygenase ( $\mathrm{RuBis} \mathrm{CO})$ is directly regulated by an enzyme called RuBisCO activase with a chaperone-like function [21]. However, this does not appear to be a general mechanism among cyanobacteria, as the respective enzyme could be found only in a few species [21].

On the contrary, the small 'chloroplast protein of $12 \mathrm{kDa}$ ' (CP12-74 aa, $8.3 \mathrm{kDA}$ in Synechocystis) seems to be universally distributed among organisms performing oxygenic photosynthesis. $\mathrm{CP} 12$ presents an additional layer of regulation [22]. Under dark conditions, the protein forms a supramolecular complex with the enzymes glyceraldehyde-3-phosphate dehydrogenase (GAPDH) and phosphoribulokinase (PRK) and thereby inhibits their activity [23,24] (Figure 1). Both enzymes are important regulatory points of the $\mathrm{CB}$ because they act at the branching points of the $\mathrm{CB}$ and OPP. In an ATP-consuming step PRK produces the RuBisCO substrate ribulose 1,5-bisphosphate from the OPP intermediate ribulose 5-phosphate. GAPDH uses NADPH to produce glyceraldehyde 3-phosphate, 
which is the main exit point of the CB and also part of the OPP. Inhibition of these two enzymes therefore helps the cell to preserve energy, when the photosynthetic light reaction is not active.

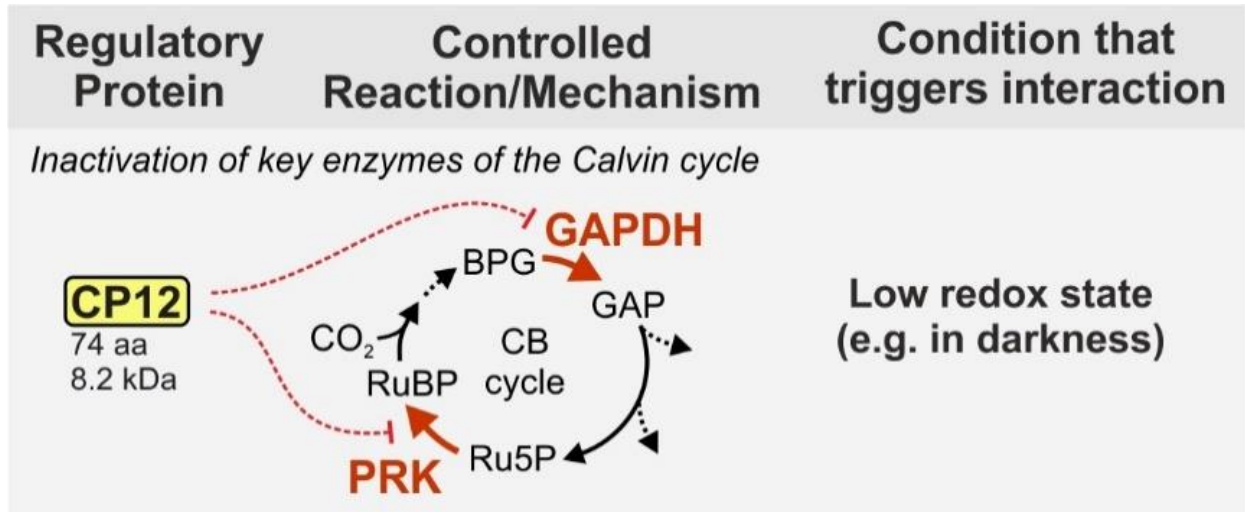

Figure 1. Function of the small protein $\mathrm{CP} 12$ in cyanobacteria. $\mathrm{CP} 12$ inhibits the $\mathrm{CB}$ cycle via complex formation with two key enzymes, PRK and GAPDH. The complex formation is initiated by a low redox status of the cell (e.g., low availability of reduction equivalents) and dinucleotide availability signals (e.g., changes in the $\mathrm{NADP}(\mathrm{H}) / \mathrm{NAD}(\mathrm{H})$ ratio) like they occur during transition from light to darkness. The protein size is given for the model strain Synechocystis. BPG-1,3-bisphopshoglycerate, GAP-glyceraldehyde 3-phosphate, Ru5P—ribose 5-phosphate, RuBP—ribulose 1,5 bisphosphate, GAPDH—glyceraldehyde 3-phosphate dehydrogenase, PRK-phosporibulokinase, CB cycle-Calvin-Benson cycle.

CP12 contains four conserved cysteine residues, two at each end. Under oxidizing conditions these cysteine residues form two terminal loops, which enable complex formation with first GADPH and then PRK [25-27]. Binding of GAPDH leads to a conformational change of CP12, which results in an extensive negative charge potential on its molecular surface. This negative charge potential mediates the binding of its N-terminal loop with PRK [25]. The formed complex drastically reduces the activity of both enzymes [28]. The complex formation is modulated by the ratio of NADP(H) to $\operatorname{NAD}(\mathrm{H})$, which decreases to almost $50 \%$ upon transition from light to darkness, and the redox status of the cell $[27,29]$. Compared to wild-type (WT), CP12-deficient cells are unable to regulate the $\mathrm{CB}$ and hence, grow slower under fluctuating light conditions, while there is no difference under continuous light conditions [29]. Interestingly, cyanophages infecting marine picocyanobacteria of the genera Prochlorococcus and Synechococcus have been shown to express functional CP12 in their host cells, likely to shut down the $\mathrm{CB}$ and use the host's production of NADPH to fuel their own deoxynucleotide biosynthesis for replication [30].

\section{Control of Glutamine Synthetase by Proteinaceous Inactivating Factors Unique to Cyanobacteria}

Besides light and $\mathrm{CO}_{2}$, nitrogen is another important environmental factor determining cyanobacterial growth. While some cyanobacteria are able to fix dinitrogen gas [31,32] most strains rely on the uptake of reduced nitrogen sources from their environment. Cyanobacteria can utilize a variety of nitrogen sources such as nitrate, nitrite, ammonium, urea, cyanate and some amino acids (such as arginine, glutamine and glutamate) [33-37]. Nevertheless, ammonium is preferred due to a lower energy demand for its assimilation compared to other nitrogen sources $[35,38]$. The manifold of nitrogen sources as well as their changing availability requires a well-orchestrated regulatory network of nitrogen metabolism in cyanobacteria.

Assimilated nitrate and nitrite are reduced inside the cell and the resulting ammonium is incorporated into carbon skeletons via glutamate dehydrogenase and the glutamine synthetase/glutamate synthase cycle (GS/GOGAT) [35]. The key enzyme GS is well known to be regulated by reversible adenylylation in several bacterial species [39]. By contrast, the cyanobacterial GS is regulated by interaction with small proteins, the so-called GS inactivating factors (IFs) two of which have been identified in Synechocystis: IF7 
(65 aa, 7.5 kDa) and IF17 (149 aa, $16.7 \mathrm{kDa}$ ) [40]. Both IFs are synthesized under nitrogen-rich conditions and specifically bind to GS causing complete enzyme inactivation (Figure 2).

\section{Regulatory Controlled Condition that Protein Reaction/Mechanism triggers interaction}

\section{Inactivation of the key enzyme for amonium assimilation}

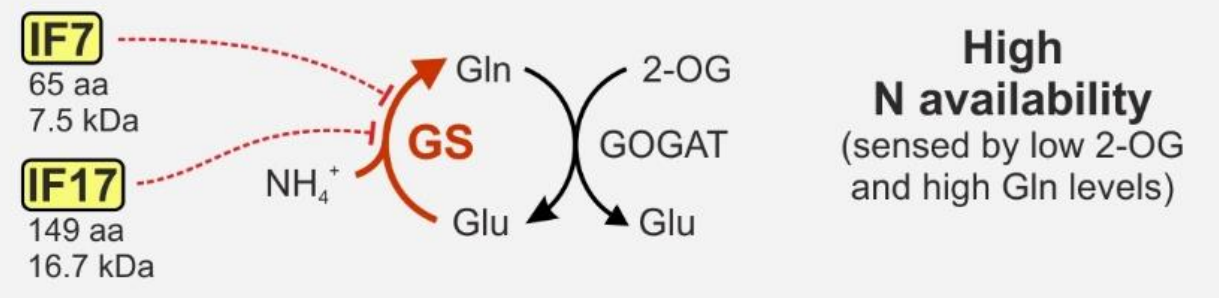

Figure 2. Inactivation of cyanobacterial GS by the interaction with small proteins. Most cyanobacteria harbor two homologous inactivating factors: IF7 and IF17, encoded by the genes gifA and gifB. The interaction with GS does not require a metabolic signal, hence IF7 and IF17 synthesis is tightly regulated at the transcriptional level by NtcA, which is further assured by regulatory RNAs acting at the post-transcriptional level. IF synthesis is stimulated by low 2-OG levels as well as high Gln levels (see text). Protein sizes are given for Synechocystis in which the proteins have initially been discovered. GS-glutamine synthetase, GOGAT_glutamine oxoglutarate aminotransferase (glutamate synthase), Gln—glutamine, Glu—glutamate, 2-OG-2-oxoglutarate.

GS activity is exclusively regulated by the abundance of IF7 and IF17 in the cell [40]. Consequently, their synthesis is target of tight control mechanisms, at the transcriptional and post-transcriptional level. For instance, the corresponding genes, gifA and gifB are repressed by NtcA [41], a universal transcriptional regulator of nitrogen assimilation in cyanobacteria, which is active and binds DNA under low-nitrogen conditions [42]. Accordingly, gifA and gifB expression rapidly increases in response to ammonium upshifts. Moreover, IF7 synthesis is negatively regulated by the small RNA NsiR4, which interacts with the gif $A$ mRNA and interferes with its translation [43]. In addition, another unique RNA-dependent mechanism has evolved, namely a glutamine riboswitch, which is present in the $5^{\prime} \mathrm{UTR}$ of the gifB transcript. It tightly controls IF17 synthesis in response to a glutamine threshold that is passed when GS activity, i.e., glutamine synthesis exceeds a certain level [44]. The peculiarities of the complex regulation of GS by direct interaction with the small proteins IF7 and IF17 are also reviewed elsewhere in more detail [45]. However, it should be noted that although IFs are unique to cyanobacteria, GS regulation by small proteins is not restricted to this group per se. For instance, GS activity is stimulated by complex formation with the 23 aa peptide sP26 and further modulated in a 2-oxoglutarate (2-OG) dependent manner by the 114 aa protein $\mathrm{GlnK}_{1}$ in the archaeal model Methanosarcina mazei $[46,47]$. Both proteins are not related to the cyanobacterial IFs, which greatly exemplifies how widespread and versatile regulatory mechanisms by small proteins are even when targeting the same enzyme.

\section{Control of the Key Enzyme of Arginine Synthesis by Direct Interaction with the PII Protein}

The PII signaling protein, a homolog to the aforementioned $\mathrm{GlnK}_{1}$, fulfills important regulatory functions and hence, is widely distributed, i.e., present in archaea, bacteria and chloroplasts of plants [48]. With a size of 112 aa and $12.25 \mathrm{kDa}$ in Synechocystis it can be defined as a small protein and will be highlighted even though it is also present in other bacteria. In cyanobacteria, the PII protein namely has distinctive regulatory functions. Unlike other bacterial phyla, cyanobacteria possess only one copy of PII [49]. Among other functions, the cyanobacterial PII protein regulates arginine synthesis by binding to the $N$-acetyl-L-glutamate kinase (NAGK), which catalyzes the second, rate limiting step of arginine synthesis from glutamate [50]. In addition to its incorporation into proteins, arginine is 
important as precursor for the nitrogen storage compound cyanophycin, which is a copolymer of aspartate and arginine [42,51]. NAGK is subject to strong feedback inhibition by arginine [52-54]. However, complex formation with PII prevents feedback inhibition of NAGK by arginine and thus strongly enhances the activity of the enzyme [55] (Figure 3).

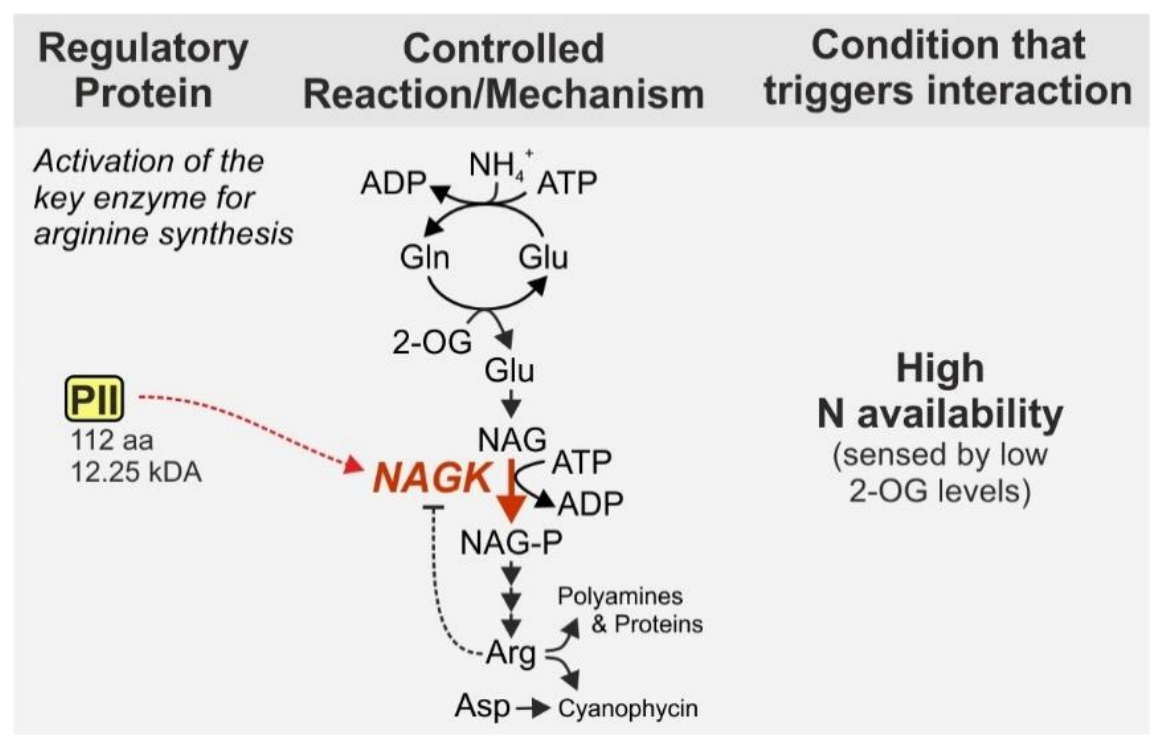

Figure 3. Regulation of N-acetyl-L-glutamate kinase (NAGK) by complex formation with the PII protein. NAGK is target of feedback inhibition by arginine, which is however minimized when PII interacts with NAGK. Thereby PII interaction enhances the flux through the rate-limiting step of arginine synthesis, which also impacts synthesis of the $\mathrm{N}$ storage compound cyanophycin. We chose NAGK as a prime example for the regulation of enzymes by direct interaction with the PII protein. Nevertheless, it should be noted that PII interacts with various other proteins including enzymes [56]. NAG—N-acetyl-L-glutamate, NAG-P-NAG phosphate, Arg—arginine, Asp—aspartate, Gln—glutamine, Glu-glutamate, 2-OG-2-oxoglutarate.

The activity of PII itself is regulated by phosphorylation, which is in contrast to heterotrophic bacteria, where PII proteins are controlled by uridylylation $[38,57]$. The phosphorylation status of PII correlates with the nitrogen status of the cell, i.e., fully phosphorylated PII protein is present in cells grown under nitrogen depleted conditions [38,58]. In contrast, the PII protein is completely dephosphorylated in cells grown in the presence of their preferred nitrogen source (ammonium) but gets phosphorylated when cells are using less preferred nitrogen sources like nitrate or nitrite [59]. The phosphorylation status of PII is dependent on the binding of both ATP and 2-OG which lead to a conformational change of PII that is recognized by the modifying enzymes PII-P phosphatase and PII kinase [60-62]. Here, 2-OG serves as a proxy for the nitrogen status of the cell, because due to the activity of the GS/GOGAT cycle the level of 2-OG correlates well with the nitrogen amount that is externally available for the cell $[56,60]$. Its function as a key regulatory protein is underlined by the fact that recombinant strains of Synechococcus elongatus PCC 7942 lacking functional PII are unable to adapt to changing environmental conditions, in particular to changes in nitrogen availability and changes from ammonium to other nitrogen sources, but also to changes in $\mathrm{CO}_{2}$ concentrations and light intensities [58].

Furthermore, unphosphorylated PII is hypothesized to regulate the uptake of nitrate and nitrite at the post-translational level $[49,63]$. Likely the PII protein binds directly to the transport protein and thereby inhibits transport [64,65]. In fact, it has been shown that PII is involved in the uptake of ammonium by interaction with the ammonium permease Amt1, inhibits the uptake of nitrate by interaction with the NrtC and NrtD subunits of the nitrate/nitrite transporter NrtABCD, and interacts with the UrtE subunit of the urea transporter UrtABCDE [66]. Additionally, the uptake of 
bicarbonate is altered in PII-knockout mutants of Synechococcus elongatus PCC 7942 [67] and no uptake of methylammonium could be measured in PII-deficient cells of Synechococcus elongatus PCC 7942 [58].

In addition, multiple other interaction partners of PII have been identified like the enzyme acetyl-CoA carboxylase (ACCase) [68] or the membrane protein PamA [69]. Some of these interaction partners are small proteins themselves, which in turn exercise metabolic control (see below).

\section{PII as an Antagonist for the Interaction of Small Proteins with Key Factors that Control Metabolic Fluxes}

Most recently, two independent studies identified another interesting example for the regulation of metabolic processes by a small protein in cyanobacteria [70,71]. Both studies suggested different names for the same protein, namely carbon flow regulator A (CfrA, Muro-Pastor et al., 2020) and PII-interacting regulator of carbon metabolism (PirC, Orthwein et al. 2020), hence we refer to both names in this case. The protein is highly conserved and can be found in almost all cyanobacterial species [70,71]. Free CfrA/PirC (112 aa, 12.27 kDa in Synechocystis) binds and inhibits 3-phosphoglycerate mutase (PGAM), an enzyme whose activity is directing carbon flux from the CB cycle towards lower glycolysis [71] (Figure 4). Hence, recombinant strains showing overproduction of CfrA/PirC accumulated excessive amounts of glycogen, while respective knockout mutants were unable to accumulate glycogen even under nitrogen depletion [70]. Instead, those strains accumulated polyhydroxybutyrate (PHB), another carbon storage compound of cyanobacteria, which derives from acetyl-CoA, i.e., reactions downstream of the one that is catalyzed by PGAM [71]. Remarkably, both studies reported complex formation of CfrA/PirC with the PII protein, which is tuned by the 2-OG level [70,71]. Thereby, PII and its interaction with CfrA/PirC determines whether or not PGAM is inhibited by interacting with the small protein. Like other bacterial groups, cyanobacteria sense the nitrogen status via the levels of 2-OG and one of the main routes of newly fixed $\mathrm{CO}_{2}$ is the synthesis of 2-OG for the assimilation of nitrogen via the GS-GOGAT cycle [59,72]. In the presence of low 2-OG levels, which signals a sufficient nitrogen status, CfrA/PirC interacts with PII. The PII-CfrA/PirC complex disassembles in presence of high 2-OG levels (e.g., under nitrogen limitation) and the released small protein then inhibits PGAM via protein-protein interaction.

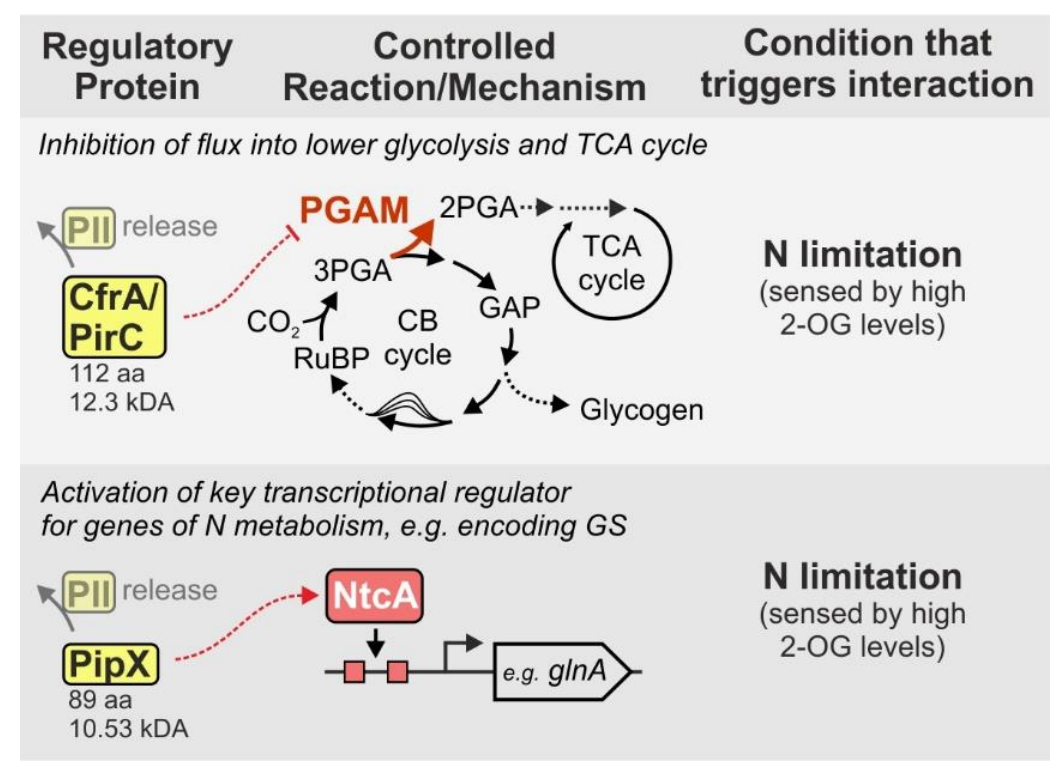

Figure 4. PII modulates and controls the interaction of further small proteins with key elements of cyanobacterial metabolism. Under conditions of sufficient nitrogen both, PipX and CfrA/PirC, form a complex with PII. Under nitrogen limitation, PII releases the small proteins that in turn interact with other target proteins thereby controlling their activity, e.g., enhancing DNA binding affinity of NtcA or inhibiting 3-phosphoglycerate mutase (PGAM). 
A similar interplay between PII and a small protein refers to the activity of the transcription factor NtcA that regulates genes majorly encoding elements of nitrogen metabolism in cyanobacteria (for a review see [42]). The small protein PipX (89 aa, $10.53 \mathrm{kDa}$ in Synechocystis) interacts with either NtcA or PII depending on the nitrogen status of the cell, sensed via 2-OG [73]. Under nitrogen sufficient conditions, i.e., low 2-OG levels, PipX is bound to PII and NtcA is inactive. In contrast, under nitrogen limiting conditions, PipX is released and interacts with NtcA. Thereby it functions as a coactivator required to enhance 2-OG-dependent binding of NtcA to its recognition sequence [73]. Albeit not exclusively, NtcA commonly acts as transcriptional activator [74] and hence, DNA binding that is triggered by 2-OG and PipX, induces sufficient expression of nitrogen assimilatory genes upon nitrogen limitation, e.g., the $g \ln A$ gene encoding GS (Figure 4).

The structural basis for different binding preferences of PipX has also been investigated $[75,76]$. However, just like PII, PipX might have even more targets and functions than currently known. For instance, binding of PipX to PII facilitates the extension of the C-terminal region of PipX and thus allow for different interaction partners than the unbound PipX protein [77]. Moreover, it was found that under nitrogen-starving conditions, only 25\% of the present PipX in Synechococcus elongatus PCC 7942 are needed to bind $100 \%$ of the present NtcA leaving $75 \%$ of the PipX protein unbound or potentially bound to unknown targets [77]. For instance, it has been shown that under nitrogen-sufficient conditions PII-bound PipX interacts with the GntR-like regulator PlmA [78]. Nevertheless, for the distinctive features of the cyanobacterial PipX protein we refer to a recent review [79].

In addition to the control that PII executes via direct interaction with enzymes such as NAGK, it appears as an antagonist of further small proteins that fulfill crucial regulatory functions in cyanobacterial metabolism. The two given examples are maybe only the tip of the iceberg and hence, further small proteins could function in a similar way. This is supported by the fact that another small protein, encoded by the ssr0692 gene in Synechocystis has been copurified with PII previously [66]. Very recently, it was shown that $\mathrm{Ssr} 0692(51 \mathrm{aa}, 5.8 \mathrm{kDa})$ is required to balance the synthesis of arginine and several other key amino acids under fluctuating $\mathrm{N}$ conditions. Indeed, the protein was confirmed to interact with PII and was hence named PII-interacting regulator of arginine synthesis (PirA, [80]).

\section{Further Examples of Small Protein Regulators Affecting the Activity of Enzymes or Transporters}

In addition to the PII protein, which is highly conserved in structure and function between different species, there are multiple so-called PII-like proteins that lack multiple consensus sequences and show rather low sequence identity [81]. One example is the protein GlnK, which is also involved in the control of nitrogen assimilation and GS regulation in various prokaryotes $[47,82,83]$. In cyanobacteria, the PII-like protein SbtB (104 aa, $11.51 \mathrm{kDa}$ in Synechocystis) has been shown to interact with the bicarbonate transporter SbtA, which thereby likely has an inhibitory effect [84,85] (Figure 5). Structural analysis of $\mathrm{SbtB}$ revealed that increasing concentrations of ATP are one signal initiating the release of SbtB from SbtA [86]. This example shows that in addition to the complex regulatory network that has been unraveled for PII over the past decades, there might be a plethora of PII-like proteins, which could also serve important regulatory functions. The question remains if these proteins have a similar manifold of interaction partners, and with this, an equivalent regulatory importance that has been shown for PII.

Another very recent example for a small protein regulator affecting enzyme activity is AcnSP (44 aa, $5.09 \mathrm{kDa}$ in Synechocystis), which is also the smallest protein presented in this review. AcnSP was proposed to stimulate the activity of its binding partner aconitase (Acn, Figure 5), and thereby impacts carbon flux towards the oxidative part of the tricarboxylic acid (TCA) cycle [87]. While the structural mechanism of protein-protein interaction and the exact biological function of AcnSP require further investigation, a potential link to high light adaptation has been already revealed [87]. 


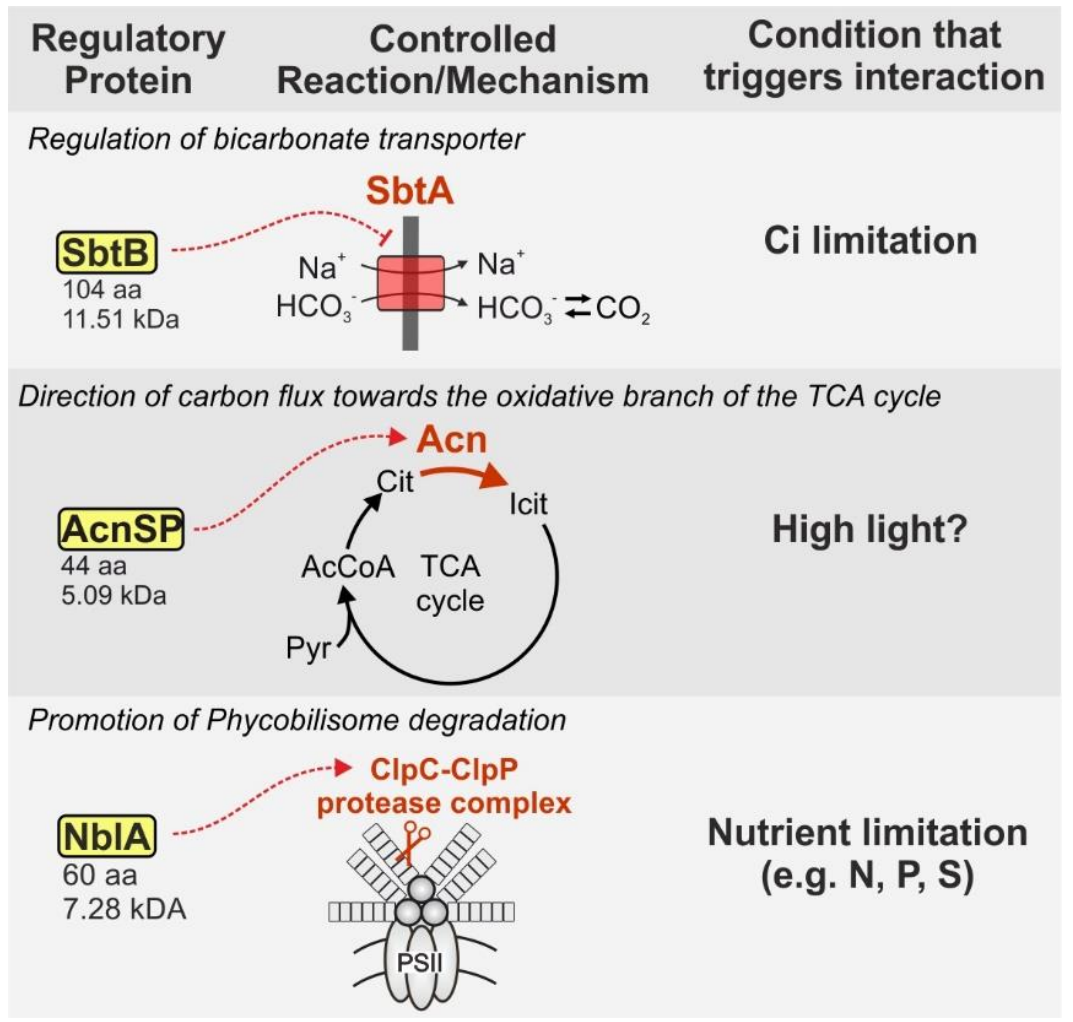

Figure 5. Further examples of small protein regulators affecting the activity of enzymes or transporters by direct interaction. The given protein sizes refer to Synechocystis. AcCoA-acetyl-CoA, Acn-aconitase, $\mathrm{Ci}$-inorganic carbon, Cit—citrate, Icit-Isocitrate, Pyr-pyruvate, PSII-photosystem II, TCA cycle-tricarboxylic acid cycle.

Upon nutrient limitation, a common reaction is the degradation of the phycobilisomes, the major light-harvesting complexes of cyanobacteria. Several small proteins are involved in the process. Knockout of the corresponding genes leads to a nonbleaching $(\mathrm{nbl})$ phenotype upon nitrogen starvation. The small protein NblA (60 aa, $7.28 \mathrm{kDa})$ was the first discovered protein involved in the process. The transcription of $n b l A$ increases moderately in phosphorous-deprived cells, but shows a much stronger response in sulfur- or nitrogen-deprived cells, leading to a partial or complete degradation of phycobilisomes, respectively [88]. Analysis of the crystal structure of NblA revealed that the protein is present as a homodimer and interacts via the C-terminus with the phycobilisomes [89]. Further studies revealed that in addition to the phycobilisome, NblA binds $\mathrm{ClpC}$ at the same time [90]. $\mathrm{ClpC}$ is part of the $\mathrm{ClpC} \bullet \mathrm{ClpP}$ protease complex. The interaction of NblA with $\mathrm{ClpC}$ initiates protein degradation by guiding the protease machinery to the phycobilisome [90] (Figure 5). Another small protein named $\mathrm{NblB}(233 \mathrm{aa}, 25.51 \mathrm{kDa})$ functions analog to $\mathrm{NblA}$ and knockouts of $n b l \mathrm{~B}$ are also unable to to degrade phycobilisomes under nutrient limiting conditions [91]. In contrast to $\mathrm{NblA}, \mathrm{NblB}$ is expressed similarly in both cells facing nutrient limitation and nutrient-sufficient conditions [91], indicating another, yet unknown, layer of regulation for this protein. Interestingly, recent results show that NblA and NblB not only facilitate degradation of phycobilisomes, but also binding and rearrangement of chromophores to phycobilisomes [92]. Thus, NblA and NblB might play an important role for short-term adjustments of the photocomplexes to optimize light harvesting under changing light conditions in natural environments.

Most recently, an additional small protein termed NblD (66 aa, $7.09 \mathrm{kDa}$ ) was described [93]. The gene locus for NblD was first discovered in a transcriptome study as a highly transcribed but not annotated region and determined as transcriptional unit (TU) 728 [94]. Later, it was discovered that TU728 accumulates upon nitrogen limitation and encodes a small protein, which was named 
NsiR6 [16]. Studies with knockout strains revealed a role in phycobilisome degradation similar to NblA and the $\beta$-subunit of phycocyanin as interaction target. Accordingly, it was named NblD. However, the exact function of $\mathrm{NblD}$ and the interplay with the other $\mathrm{Nbl}$-proteins remains to be unraveled at this point [93].

\section{The Potential of Small Proteins for Metabolic Engineering and Biotechnological Applications}

Interest in cyanobacteria as host organisms for biotechnological applications has increased steadily over the past decade [95-99]. To date, more than 20 chemicals have been synthesized in cyanobacteria directly from $\mathrm{CO}_{2}$, e.g., 1,2-propanediol, cyclohexanol, ethanol, isobutyraldehyde, isobutanol, 1-butanol, isoprene, ethylene, hexoses, cellulose, mannitol, lactic acid and fatty acids [96,98,100-102]. Theoretically, every chemical that can be produced by heterotrophic bacteria can also be produced photoautotrophically using cyanobacteria. Thereby, a direct production based on photosynthetic $\mathrm{CO}_{2}$ fixation is hypothesized to be beneficial over the intermediate $\mathrm{CO}_{2}$ fixation into biomass, required as source for a heterotrophic production process [98,103].

The growing interest in the biotechnological utilization of cyanobacteria comes with an increasing demand for advanced molecular tools for the genetic engineering of cyanobacteria, which lack far behind the toolset that is available, e.g., for E. coli $[104,105]$. Besides tools for the predictable control of gene expression like promoters [106], this also includes ways to reroute the endogenous carbon flux towards the desired reaction, e.g., blocking of competing pathways or the synthesis of storage compounds [107]. Typically, this is achieved by knocking out the gene encoding the respective synthesis, for example by insertional inactivation with an antibiotic resistance cassette. One major drawback of knockout mutants is the permanent loss of a specific gene function, which might be disadvantageous under certain conditions, in particular in the long-term under natural, i.e., steadily fluctuating conditions. For instance, knockout mutants of glycogen biosynthesis show impaired growth under fluctuating light conditions [108]. This might be problematic, for example, in outdoor bioreactors during phases of biomass production, in which product formation is not the primary interest. Another approach to control gene regulation in bioengineered strains is RNA silencing by small antisense RNA (asRNA) - a technique that has been established also in cyanobacteria as an alternative method for permanent knockouts $[109,110]$. In comparison to permanent knockouts, asRNA constructs can be controlled, for example, by an inducible promoter independently or in the same way as the respective genes for the production process. However, RNA silencing approaches can be prone to off-target effects and genetic instability of the asRNA construct in subsequent generations [111]. The latter is especially critical in photoautotrophic bacterial systems with short generation times and ideally long or even continuous cultivation intervals.

As pointed out in this review, small proteins are able to sense and implement different signals, bind several interaction partners at the same time and thereby play important regulatory roles in diverse metabolic pathways. Hence, small proteins might pose an interesting addition to the molecular tool set of cyanobacteria. In fact, a few examples can already be found in literature. For instance, the aforementioned CP12 protein has been used to engineer carbon metabolism of the cyanobacterium Synechococcus elongatus PCC 7942, i.e., to improve $\mathrm{CO}_{2}$ fixation and, together with other modifications, to increase the production of 2,3-butanediol [112]. Similarly, the carbon flow regulator CfrA/PirC together with two other modifications has been utilized to increase the production yield of the plastic alternative polyhydroxybutyrate (PHB) in Synechocystis from 15 to $63 \%$ per cell dry weight (CDW) and even to $81 \%$ with additional feeding of acetate [113]. In addition, targeted engineering of existing regulatory proteins may allow the generation of variants exhibiting different binding characteristic compared to the native protein. The principle has already been demonstrated for variants of the PII protein. For instance, variants mimicking either the phosphorylated or the unphosphorylated state of the protein resulted in strains with different nitrogen uptake characteristics compared to WT cells [63]. Moreover, other variants led to a constitutive interaction with NAGK, accompanied by enhanced arginine synthesis and cyanophycin accumulation [114]. Altogether, the greater chemical diversity of 
proteins compared to small pieces of RNA may result in a control mechanism that is less prone to off targets and more stable over several generations.

Author Contributions: Conceptualization, S.K.; original draft preparation, F.B.; review and editing, F.B. and S.K. All authors have read and agreed to the published version of the manuscript.

Funding: The work was financially supported by the Deutsche Forschungsgemeinschaft (DFG; Grant KL 3114/2-1 to S.K.). We acknowledge the use of the facilities of the Centre for Biocatalysis (MiKat) at the Helmholtz Centre for Environmental Research. The Helmholtz Centre for Environmental Research is supported by the European Regional Development Funds (EFRE, Europe funds Saxony) and the Helmholtz Association.

Conflicts of Interest: The authors declare no conflict of interest.

\section{References}

1. Labeit, S.; Kolmerer, B. Titins: Giant proteins in charge of muscle ultrastructure and elasticity. Science 1995, 270, 293-296. [CrossRef] [PubMed]

2. Opitz, C.A.; Kulke, M.; Leake, M.C.; Neagoe, C.; Hinssen, H.; Hajjar, R.J.; Linke, W.A. Damped elastic recoil of the titin spring in myofibrils of human myocardium. Proc. Natl. Acad. Sci. USA 2003, 100, 12688-12693. [CrossRef] [PubMed]

3. Galindo, M.I.; Pueyo, J.I.; Fouix, S.; Bishop, S.A.; Couso, J.P. Peptides encoded by short ORFs control development and define a new eukaryotic gene family. PLoS Biol. 2007, 5, 1052-1062. [CrossRef] [PubMed]

4. Zhang, J. Protein-length distributions for the three domains of life. Trends Genet. 2000, 16, 107-109. [CrossRef]

5. Miravet-Verde, S.; Ferrar, T.; Espadas-García, G.; Mazzolini, R.; Gharrab, A.; Sabido, E.; Serrano, L.; Lluch-Senar, M. Unraveling the hidden universe of small proteins in bacterial genomes. Mol. Syst. Biol. 2019, 15, 1-17. [CrossRef] [PubMed]

6. Storz, G.; Wolf, Y.I.; Ramamurthi, K.S. Small proteins can no Longer be ignored. Annu. Rev. Biochem. 2014, 83, 753-777. [CrossRef] [PubMed]

7. Holmgren, A. Thioredoxin and glutaredoxin systems. Methods Enzymol. 1989, 264, 286-296. [CrossRef]

8. Arnér, E.S.J.; Holmgren, A. Physiological functions of thioredoxin and thioredoxin reductase. Eur. J. Biochem. 2000, 267, 6102-6109. [CrossRef] [PubMed]

9. Lu, J.; Holmgren, A. The thioredoxin antioxidant system. Free Radic. Biol. Med. 2014, 66, 75-87. [CrossRef]

10. Su, M.; Ling, Y.; Yu, J.; Wu, J.; Xiao, J. Small proteins: Untapped area of potential biological importance. Front. Genet. 2013, 4, 286. [CrossRef]

11. Kliemt, J.; Soppa, J. Diverse functions of small RNAs (sRNAs) in halophilic Archaea: From non-coding regulatory sRNAs to microprotein-Encoding sRNAs. In RNA Metabolism and Gene Expression in Archaea, 1st ed.; Clouet-d'Orval, B., Ed.; Springer: Dordrecht, The Netherlands, 2017; Volume 5, pp. 225-242.

12. Grasse, N.; Mamedov, F.; Becker, K.; Styring, S.; Rögner, M.; Nowaczyk, M.M. Role of novel dimeric photosystem II (PSII)-Psb27 protein complex in PSII repair. J. Biol. Chem. 2011, 286, 29548-29555. [CrossRef]

13. Rexroth, S.; Rexroth, D.; Veit, S.; Plohnke, N.; Cormann, K.U.; Nowaczyk, M.M.; Rögner, M. Functional characterization of the small regulatory subunit PetP from the cytochrome b6f complex in Thermosynechococcus elongatus. Plant Cell 2014, 26, 3435-3448. [CrossRef] [PubMed]

14. Kashino, Y.; Lauber, W.M.; Carroll, J.A.; Wang, Q.; Whitmarsh, J.; Satoh, K.; Pakrasi, H.B. Proteomic analysis of a highly active photosystem II preparation from the cyanobacterium Synechocystis sp. PCC 6803 reveals the presence of novel polypeptides. Biochemistry 2002, 41, 8004-8012. [CrossRef] [PubMed]

15. Guskov, A.; Kern, J.; Gabdulkhakov, A.; Broser, M.; Zouni, A.; Saenger, W. Cyanobacterial photosystem II at 2.9- $\AA$ resolution and the role of quinones, lipids, channels and chloride. Nat. Struct. Mol. Biol. 2009, 16, 334-342. [CrossRef] [PubMed]

16. Baumgartner, D.; Kopf, M.; Klähn, S.; Steglich, C.; Hess, W.R. Small proteins in cyanobacteria provide a paradigm for the functional analysis of the bacterial micro-proteome. BMC Microbiol. 2016, 16, 1-15. [CrossRef] [PubMed]

17. Zuber, P. A peptide profile of the Bacillus subtilis genome. Peptides 2001, 22, 1555-1577. [CrossRef]

18. Yang, X.; Tschaplinski, T.J.; Hurst, G.B.; Jawdy, S.; Abraham, P.E.; Lankford, P.K.; Adams, R.M.; Shah, M.B.; Hettich, R.L.; Lindquist, E.; et al. Discovery and annotation of small proteins using genomics, proteomics, and computational approaches. Genome Res. 2011, 21, 634-641. [CrossRef] 
19. Chen, X.; Schreiber, K.; Appel, J.; Makowka, A.; Fähnrich, B.; Roettger, M.; Hajirezaei, M.R.; Sönnichsen, F.D.; Schönheit, P.; Martin, W.F.; et al. The Entner-Doudoroff pathway is an overlooked glycolytic route in cyanobacteria and plants. Proc. Natl. Acad. Sci. USA 2016, 113, 5441-5446. [CrossRef]

20. Stitt, M. Metabolic Regulation of Photosynthesis. In Photosynthesis and the Environment, 1st ed.; Baker, N.A., Ed.; Springer: Dordrecht, The Netherlands, 2006; Volume 5, pp. 151-190.

21. Portis, A.R. Rubisco activase-Rubisco's catalytic chaperone. Photosynth. Res. 2003, 75, 11-27. [CrossRef]

22. Groben, R.; Kaloudas, D.; Raines, C.A.; Offmann, B.; Maberly, S.C.; Gontero, B. Comparative sequence analysis of $\mathrm{CP} 12$, a small protein involved in the formation of a Calvin cycle complex in photosynthetic organisms. Photosynth. Res. 2010, 103, 183-194. [CrossRef]

23. Pohlmeyer, K.; Paap, B.K.; Soll, J.; Wedel, N. CP12: A small nuclear-encoded chloroplast protein provides novel insights into higher-plant GAPDH evolution. Plant Mol. Biol. 1996, 32, 969-978. [CrossRef]

24. Wedel, N.; Soll, J.; Paap, B.K. CP12 provides a new mode of light regulation of Calvin cycle activity in higher plants. Proc. Natl. Acad. Sci. USA 1997, 94, 10479-10484. [CrossRef] [PubMed]

25. Matsumura, H.; Kai, A.; Maeda, T.; Tamoi, M.; Satoh, A.; Tamura, H.; Hirose, M.; Ogawa, T.; Kizu, N.; Wadano, A.; et al. Structure basis for the regulation of glyceraldehyde-3-phosphate dehydrogenase activity via the intrinsically disordered protein CP12. Structure 2011, 19, 1846-1854. [CrossRef] [PubMed]

26. Reichmann, D.; Jakob, U. The roles of conditional disorder in redox proteins. Curr. Opin. Struct. Biol. 2013, 23, 436-442. [CrossRef] [PubMed]

27. McFarlane, C.R.; Shah, N.R.; Kabasakal, B.V.; Echeverria, B.; Cotton, C.A.R.; Bubeck, D.; Murray, J.W. Structural basis of light-induced redox regulation in the Calvin-Benson cycle in cyanobacteria. Proc. Natl. Acad. Sci. USA 2019, 116, 20984-20990. [CrossRef] [PubMed]

28. Graciet, E.; Lebreton, S.; Camadro, J.M.; Gontero, B. Characterization of native and recombinant A4 glyceraldehyde 3-phosphate dehydrogenase: Kinetic evidence for conformation changes upon association with the small protein CP12. Eur. J. Biochem. 2003, 270, 129-136. [CrossRef]

29. Tamoi, M.; Miyazaki, T.; Fukamizo, T.; Shigeoka, S. The Calvin cycle in cyanobacteria is regulated by CP12 via the NAD $(\mathrm{H}) / \mathrm{NADP}(\mathrm{H})$ ratio under light/dark conditions. Plant J. 2005, 42, 504-513. [CrossRef]

30. Thompson, L.R.; Zeng, Q.; Kelly, L.; Huang, K.H.; Singer, A.U.; Stubbe, J.A.; Chisholm, S.W. Phage auxiliary metabolic genes and the redirection of cyanobacterial host carbon metabolism. Proc. Natl. Acad. Sci. USA 2011, 108. [CrossRef]

31. Esteves-Ferreira, A.A.; Cavalcanti, J.H.F.; Vaz, M.G.M.V.; Alvarenga, L.V.; Nunes-Nesi, A.; Araújo, W.L. Cyanobacterial nitrogenases: Phylogenetic diversity, regulation and functional predictions. Genet. Mol. Biol. 2017, 40, 261-275. [CrossRef] [PubMed]

32. Zehr, J.P. Nitrogen fixation by marine cyanobacteria. Trends Microbiol. 2011, 19, 162-173. [CrossRef]

33. Quintero, M.J.; Montesinos, M.L.; Herrero, A.; Flores, E. Identification of genes encoding amino acid permeases by inactivation of selected ORFs from the Synechocystis genomic sequence. Genome Res. 2001, 11, 2034-2040. [CrossRef]

34. Valladares, A.; Montesinos, M.L.; Herrero, A.; Flores, E. An ABC-type, high-affinity urea permease identified in cyanobacteria. Mol. Microbiol. 2002, 43, 703-715. [CrossRef] [PubMed]

35. Flores, E.; Frías, J.E.; Rubio, L.M.; Herrero, A. Photosynthetic nitrate assimilation in cyanobacteria. Photosynth. Res. 2005, 83, 117-133. [CrossRef]

36. Muro-Pastor, M.I.; Reyes, J.C.; Florencio, F.J. Ammonium assimilation in cyanobacteria. Photosynth. Res. 2005, 83, 135-150. [CrossRef] [PubMed]

37. Kamennaya, N.A.; Chernihovsky, M.; Post, A.F. The cyanate utilization capacity of marine unicellular Cyanobacteria. Limnol. Oceanogr. 2008, 53, 2485-2494. [CrossRef]

38. Forchhammer, K.; Tandeau De Marsac, N. The P(II) protein in the cyanobacterium Synechococcus sp. strain PCC 7942 is modified by serine phosphorylation and signals the cellular N-status. J. Bacteriol. 1994, 176, 84-91. [CrossRef] [PubMed]

39. Merrick, M.J.; Edwards, R.A. Nitrogen control in bacteria. Microbiol. Rev. 1995, 59, 604-622. [CrossRef]

40. García-Domínguez, M.; Reyes, J.C.; Florencio, F.J. Glutamine synthetase inactivation by protein-protein interaction. Proc. Natl. Acad. Sci. USA 1999, 96, 7161-7166. [CrossRef]

41. García-Domínguez, M.; Reyes, J.C.; Florencio, F.J. NtcA represses transcription of gifA and gifB, genes that encode inhibitors of glutamine synthetase type I from Synechocystis sp. PCC 6803. Mol. Microbiol. 2000, 35, 1192-1201. [CrossRef] 
42. Herrero, A.; Muro-Pastor, A.M.; Flores, E. Nitrogen control in cyanobacteria. J. Bacteriol. 2001, 183, 411-425. [CrossRef]

43. Klähn, S.; Schaal, C.; Georg, J.; Baumgartner, D.; Knippen, G.; Hagemann, M.; Muro-Pastor, A.M.; Hess, W.R. The sRNA NsiR4 is involved in nitrogen assimilation control in cyanobacteria by targeting glutamine synthetase inactivating factor IF7. Proc. Natl. Acad. Sci. USA 2015, 112, E6243-E6252. [CrossRef]

44. Klähn, S.; Bolay, P.; Wright, P.R.; Atilho, R.M.; Brewer, K.I.; Hagemann, M.; Breaker, R.R.; Hess, W.R. A glutamine riboswitch is a key element for the regulation of glutamine synthetase in cyanobacteria. Nucleic Acids Res. 2018, 46, 10082-10094. [CrossRef]

45. Bolay, P.; Muro-Pastor, M.I.; Florencio, F.J.; Klähn, S. The distinctive regulation of cyanobacterial glutamine synthetase. Life 2018, 8, 52. [CrossRef]

46. Gutt, M.; Jordan, B.; Weidenbach, K.; Gudzuhn, M.; Kiessling, C.; Cassidy, L.; Helbig, A.; Tholey, A.; Pyper, D.; Schwalbe, H.; et al. Small protein 26 interacts and enhances glutamine synthetase activity in Methanosarcina mazei. bioRxiv 2020. [CrossRef]

47. Ehlers, C.; Weidenbach, K.; Veit, K.; Forchhammer, K.; Schmitz, R.A. Unique mechanistic features of post-translational regulation of glutamine synthetase activity in Methanosarcina mazei strain Gö1 in response to nitrogen availability. Mol. Microbiol. 2005, 55, 1841-1854. [CrossRef]

48. Huergo, L.F.; Chandra, G.; Merrick, M. PII signal transduction proteins: Nitrogen regulation and beyond. FEMS Microbiol. Rev. 2013, 37, 251-283. [CrossRef] [PubMed]

49. Lee, H.M.; Flores, E.; Herrero, A.; Houmard, J.; Tandeau De Marsac, N. A role for the signal transduction protein P(II) in the control of nitrate/nitrite uptake in a cyanobacterium. FEBS Lett. 1998, 427, 291-295. [CrossRef]

50. Heinrich, A.; Maheswaran, M.; Ruppert, U.; Forchhammer, K. The Synechococcus elongatus PII signal transduction protein controls arginine synthesis by complex formation with N-acetyl-L-glutamate kinase. Mol. Microbiol. 2004, 52, 1303-1314. [CrossRef]

51. Simon, R.D. Cyanophycin Granules from the Blue-Green Alga Anabaena cylindrica: A Reserve Material Consisting of Copolymers of Aspartic Acid and Arginine. Proc. Natl. Acad. Sci. USA 1971, 68, 265-267. [CrossRef]

52. Pauwels, K.; Abadjieva, A.; Hilven, P.; Stankiewicz, A.; Crabeel, M. The N-acetylglutamate synthase/N-acetylglutamate kinase metabolon of Saccharomyces cerevisiae allows coordinated feedback regulation of the first two steps in arginine biosynthesis. Eur. J. Biochem. 2003, 270, 1014-1024. [CrossRef]

53. Caldovic, L.; Tuchman, M. N -Acetylglutamate and its changing role through evolution. Biochem J. 2003, 290, 279-290. [CrossRef] [PubMed]

54. Cunin, R.; Glansdorff, N.; Pierard, A.; Stalon, V. Biosynthesis and metabolism of arginine in bacteria. Microbiol. Rev. 1986, 50, 314-352. [CrossRef] [PubMed]

55. Maheswaran, M.; Urbanke, C.; Forchhammer, K. Complex formation and catalytic activation by the PII signaling protein of N-acetyl-L-glutamate kinase from Synechococcus elongatus strain PCC 7942. J. Biol. Chem. 2004, 279, 55202-55210. [CrossRef] [PubMed]

56. Forchhammer, K. PII signal transducers: Novel functional and structural insights. Trends Microbiol. 2008, 16, 65-72. [CrossRef] [PubMed]

57. Maheswaran, M.; Forchhammer, K. Carbon-source-dependent nitrogen regulation in Escherichia coli is mediated through glutamine-dependent GlnB signalling. Microbiology 2003, 149, 2163-2172. [CrossRef] [PubMed]

58. Forchhammer, K.; Tandeau De Marsac, N. Functional analysis of the phosphoprotein P(II) ( $g \ln B$ gene product) in the cyanobacterium Synechococcus sp. strain PCC 7942. J. Bacteriol. 1995, 177, 2033-2040. [CrossRef] [PubMed]

59. Forchhammer, K. Global carbon/nitrogen control by PII signal transduction in cyanobacteria: From signals to targets. FEMS Microbiol. Rev. 2004, 28, 319-333. [CrossRef]

60. Forchhammer, K. The PII protein in Synechococcus PCC 7942 senses and signals 2-oxoglutarate under ATP-replete conditions. In The Phototrophic Prokaryotes, 1st ed.; Peschek, G.A., Löffelhardt, W., Schmetterer, G., Eds.; Springer: Berlin/Heidelberg, Germany, 1999; pp. 549-553.

61. Forchhammer, K.; De Marsac, N.T. Phosphorylation of the P(II) protein ( $g \ln B$ gene product) in the cyanobacterium Synechococcus sp. strain PCC 7942: Analysis of in vitro kinase activity. J. Bacteriol. 1995, 177, 5812-5817. [CrossRef] 
62. Kloft, N.; Rasch, G.; Forchhammer, K. Protein phosphatase PphA from Synechocystis sp. PCC 6803: The physiological framework of PII-P dephosphorylation. Microbiology 2005, 151, 1275-1283. [CrossRef]

63. Lee, H.M.; Flores, E.; Forchhammer, K.; Herrero, A.; Tandeau De Marsac, N. Phosphorylation of the signal transducer $\mathrm{P}(\mathrm{II})$ protein and an additional effector are required for the $\mathrm{P}(\mathrm{II})$-mediated regulation of nitrate and nitrite uptake in the cyanobacterium Synechococcus sp. PCC 7942. Eur. J. Biochem. 2000, 267, 591-600. [CrossRef]

64. Heinrich, A.; Woyda, K.; Brauburger, K.; Meiss, G.; Detsch, C.; Stülke, J.; Forchhammer, K. Interaction of the membrane-bound GlnK-AmtB complex with the master regulator of nitrogen metabolism TnrA in Bacillus subtilis. J. Biol. Chem. 2006, 281, 34909-34917. [CrossRef] [PubMed]

65. Radchenko, M.V.; Thornton, J.; Merrick, M. Control of AmtB-GlnK complex formation by intracellular levels of ATP, ADP, and 2-oxoglutarate. J. Biol. Chem. 2010, 285, 31037-31045. [CrossRef] [PubMed]

66. Watzer, B.; Spät, P.; Neumann, N.; Koch, M.; Sobotka, R.; MacEk, B.; Hennrich, O.; Forchhammer, K. The signal transduction protein PII controls ammonium, nitrate and urea uptake in cyanobacteria. Front. Microbiol. 2019, 10, 1-20. [CrossRef] [PubMed]

67. Hisbergues, M.; Jeanjean, R.; Joset, F.; Tandeau De Marsac, N.; Bédu, S. Protein PII regulates both inorganic carbon and nitrate uptake and is modified by a redox signal in Synechocystis PCC 6803. FEBS Lett. 1999, 463, 216-220. [CrossRef]

68. Hauf, W.; Schmid, K.; Gerhardt, E.C.M.; Huergo, L.F.; Forchhammer, K. Interaction of the nitrogen regulatory protein $\mathrm{GlnB}$ (PII) with biotin carboxyl carrier protein (BCCP) controls acetyl-CoA levels in the cyanobacterium Synechocystis sp. PCC 6803. Front. Microbiol. 2016, 7, 1-14. [CrossRef]

69. Osanai, T.; Sato, S.; Tabata, S.; Tanaka, K. Identification of PamA as a PII-binding membrane protein important in nitrogen-related and sugar-catabolic gene expression in Synechocystis sp. PCC 6803. J. Biol. Chem. 2005, 280, 34684-34690. [CrossRef]

70. Muro-Pastor, M.I.; Cutillas-Farray, Á.; Pérez-Rodríguez, L.; Pérez-Saavedra, J.; Vega-de Armas, A.; Paredes, A.; Robles-Rengel, R.; Florencio, F.J. CfrA, a novel carbon flow regulator, adapts carbon metabolism to nitrogen deficiency in cyanobacteria. Plant Physiol. 2020. [CrossRef]

71. Orthwein, T.; Scholl, J.; Spät, P.; Lucius, S.; Koch, M.; Macek, B.; Hagemann, M.; Forchhammer, K. The Novel PII-Interacting Regulator PirC (Sl10944) Identifies 3-Phosphoglycerate Mutase (PGAM) as Central Control Point of Carbon Storage Metabolism in Cyanobacteria. bioRxiv 2020. [CrossRef]

72. Leigh, J.A.; Dodsworth, J.A. Nitrogen regulation in bacteria and archaea. Annu. Rev. Microbiol. 2007, 61, 349-377. [CrossRef]

73. Espinosa, J.; Forchhammer, K.; Burillo, S.; Contreras, A. Interaction network in cyanobacterial nitrogen regulation: PipX, a protein that interacts in a 2-oxoglutarate dependent manner with PII and NtcA. Mol. Microbiol. 2006, 61, 457-469. [CrossRef]

74. Giner-Lamia, J.; Robles-Rengel, R.; Hernández-Prieto, M.A.; Isabel Muro-Pastor, M.; Florencio, F.J.; Futschik, M.E. Identification of the direct regulon of NtcA during early acclimation to nitrogen starvation in the cyanobacterium Synechocystis sp. PCC 6803. Nucleic Acids Res. 2017, 45, 11800-11820. [CrossRef] [PubMed]

75. Llácer, J.L.; Espinosa, J.; Castells, M.A.; Contreras, A.; Forchhammer, K.; Rubio, V. Structural basis for the regulation of NtcA-dependent transcription by proteins PipX and PII. Proc. Natl. Acad. Sci. USA 2010, 107, 15397-15402. [CrossRef] [PubMed]

76. Zhao, M.-X.; Jiang, Y.-L.; He, Y.-X.; Chen, Y.-F.; Teng, Y.-B.; Chen, Y.; Zhang, C.-C.; Zhou, C.-Z. Structural basis for the allosteric control of the global transcription factor NtcA by the nitrogen starvation signal 2-oxoglutarate. Proc. Natl. Acad. Sci. USA 2010, 107, 12487-12492. [CrossRef]

77. Forcada-Nadal, A.; Llácer, J.L.; Contreras, A.; Marco-Marín, C.; Rubio, V. The PII-NAGK-PipX-NtcA regulatory axis of cyanobacteria: A tale of changing partners, allosteric effectors and non-covalent interactions. Front. Mol. Biosci. 2018, 5, 1-18. [CrossRef]

78. Labella, J.I.; Obrebska, A.; Espinosa, J.; Salinas, P.; Forcada-Nadal, A.; Tremiño, L.; Rubio, V.; Contreras, A. Expanding the cyanobacterial nitrogen regulatory network: The GntR-like regulator PlmA interacts with the PII-PipX complex. Front. Microbiol. 2016, 7, 1-17. [CrossRef]

79. Labella, J.I.; Cantos, R.; Salinas, P.; Espinosa, J.; Contreras, A. Distinctive features of PipX, a unique signaling protein of cyanobacteria. Life 2020, 10, 79. [CrossRef] [PubMed] 
80. Bolay, P.; Muro-pastor, M.I.; Rozbeh, R.; Timm, S.; Hagemann, M.; Florencio, F.J.; Forchhammer, K.; Klähn, S. The novel PII-interacting protein PirA regulates flux into the cyanobacterial ornithine-ammonia cycle. bioRxiv 2020. [CrossRef]

81. Forchhammer, K.; Lüddecke, J. Sensory properties of the PII signalling protein family. FEBS J. 2016, 283, 425-437. [CrossRef]

82. Van Heeswijk, W.C.; Hoving, S.; Molenaar, D.; Stegeman, B.; Kahn, D.; Westerhoff, H.V. An alternative $\mathrm{P}(\mathrm{II})$ protein in the regulation of glutamine synthetase in Escherichia coli. Mol. Microbiol. 1996, 21, 133-146. [CrossRef]

83. Atkinson, M.R.; Ninfa, A.J. Role of the GlnK signal transduction protein in the regulation of nitrogen assimilation in Escherichia coli. Mol. Microbiol. 1998, 29, 431-447. [CrossRef]

84. Du, J.; Förster, B.; Rourke, L.; Howitt, S.M.; Price, G.D. Characterisation of cyanobacterial bicarbonate transporters in E. coli shows that SbtA homologs are functional in this heterologous expression system. PLoS ONE 2014, 9, e115905. [CrossRef] [PubMed]

85. Selim, K.A.; Haase, F.; Hartmann, M.D.; Hagemann, M.; Forchhammer, K. PII-like signaling protein SbtB links cAMP sensing with cyanobacterial inorganic carbon response. Proc. Natl. Acad. Sci. USA 2018, 115, E4861-E4869. [CrossRef] [PubMed]

86. Kaczmarski, J.A.; Hong, N.S.; Mukherjee, B.; Wey, L.T.; Rourke, L.; Förster, B.; Peat, T.S.; Price, G.D.; Jackson, C.J. Structural basis for the allosteric regulation of the SbtA bicarbonate transporter by the PII-like protein, SbtB, from Cyanobium sp. PCC7001. Biochemistry 2019, 58, 5030-5039. [CrossRef] [PubMed]

87. de Alvarenga, L.V.; Hess, W.R.; Hagemann, M. AcnSP-A novel small protein regulator of aconitase activity in the cyanobacterium Synechocystis sp. PCC 6803. Front. Microbiol. 2020, 11, 1-12. [CrossRef]

88. Collier, J.L.; Grossman, A.R. A small polypeptide triggers complete degradation of light-harvesting phycobiliproteins in nutrient-deprived cyanobacteria. EMBO J. 1994, 13, 1039-1047. [CrossRef] [PubMed]

89. Bienert, R.; Baier, K.; Volkmer, R.; Lockau, W.; Heinemann, U. Crystal structure of NblA from Anabaena sp. PCC 7120, a small protein playing a key role in phycobilisome degradation. J. Biol. Chem. 2006, 281, 5216-5223. [CrossRef] [PubMed]

90. Karradt, A.; Sobanski, J.; Mattow, J.; Lockau, W.; Baier, K. NblA, a key protein of phycobilisome degradation, interacts with ClpC, a HSP100 chaperone partner of a cyanobacterial Clp protease. J. Biol. Chem. 2008, 283, 32394-32403. [CrossRef]

91. Dolganov, N.; Grossman, A.R. A polypeptide with similarity to phycocyanin $\alpha$-subunit phycocyanobilin lyase involved in degradation of phycobilisomes. J. Bacteriol. 1999, 181, 610-617. [CrossRef]

92. Hu, P.P.; Hou, J.Y.; Xu, Y.L.; Niu, N.N.; Zhao, C.; Lu, L.; Zhou, M.; Scheer, H.; Zhao, K.H. The role of lyases, $\mathrm{NblA}$ and $\mathrm{NblB}$ proteins and bilin chromophore transfer in restructuring the cyanobacterial light-harvesting complex. Plant J. 2020, 102, 529-540. [CrossRef]

93. Krauspe, V.; Fahrner, M.; Spät, P.; Steglich, C.; Frankenberg-Dinkel, N.; Macek, B.; Schilling, O.; Hess, W.R. Discovery of a novel small protein factor involved in the coordinated degradation of phycobilisomes in cyanobacteria. bioRxiv 2020. [CrossRef]

94. Kopf, M.; Klähn, S.; Scholz, I.; Matthiessen, J.K.F.; Hess, W.R.; Voß, B. Comparative analysis of the primary transcriptome of Synechocystis sp. PCC 6803. DNA Res. 2014, 21, 527-539. [CrossRef]

95. Hitchcock, A.; Hunter, C.N.; Canniffe, D.P. Progress and challenges in engineering cyanobacteria as chassis for light-driven biotechnology. Microb. Biotechnol. 2020, 13, 363-367. [CrossRef] [PubMed]

96. Savakis, P.; Hellingwerf, K.J. Engineering cyanobacteria for direct biofuel production from $\mathrm{CO}_{2}$. Curr. Opin. Biotechnol. 2015, 33, 8-14. [CrossRef] [PubMed]

97. Hagemann, M.; Hess, W.R. Systems and synthetic biology for the biotechnological application of cyanobacteria. Curr. Opin. Biotechnol. 2018, 49, 94-99. [CrossRef] [PubMed]

98. Ducat, D.C.; Way, J.C.; Silver, P.A. Engineering cyanobacteria to generate high-value products. Trends Biotechnol. 2011, 29, 95-103. [CrossRef] [PubMed]

99. Abed, R.M.M.; Dobretsov, S.; Sudesh, K. Applications of cyanobacteria in biotechnology. J. Appl. Microbiol. 2009, 106, 1-12. [CrossRef] [PubMed]

100. Rosgaard, L.; de Porcellinis, A.J.; Jacobsen, J.H.; Frigaard, N.U.; Sakuragi, Y. Bioengineering of carbon fixation, biofuels, and biochemicals in cyanobacteria and plants. J. Biotechnol. 2012, 162, 134-147. [CrossRef] [PubMed] 
101. David, C.; Schmid, A.; Adrian, L.; Wilde, A.; Bühler, K. Production of 1,2-propanediol in photoautotrophic Synechocystis is linked to glycogen turn-over. Biotechnol. Bioeng. 2018, 115, 300-311. [CrossRef] [PubMed]

102. Hoschek, A.; Toepel, J.; Hochkeppel, A.; Karande, R.; Bühler, B.; Schmid, A. Light-dependent and aeration-independent gram-scale hydroxylation of cyclohexane to cyclohexanol by CYP450 harboring Synechocystis sp. PCC 6803. Biotechnol. J. 2019, 14, 1-10. [CrossRef]

103. Van Dam, J.E.G.; De Klerk-Engels, B.; Struik, P.C.; Rabbinge, R. Securing renewable resource supplies for changing market demands in a bio-based economy. Ind. Crops Prod. 2005, 21, 129-144. [CrossRef]

104. Wang, B.; Wang, J.; Meldrum, D.R. Application of synthetic biology in cyanobacteria and algae. Front. Microbiol. 2012, 3, 1-15. [CrossRef] [PubMed]

105. Markley, A.L.; Begemann, M.B.; Clarke, R.E.; Gordon, G.C.; Pfleger, B.F. Synthetic biology toolbox for controlling gene expression in the cyanobacterium Synechococcus sp. strain PCC 7002. ACS Synth. Biol. 2015, 4, 595-603. [CrossRef] [PubMed]

106. Englund, E.; Liang, F.; Lindberg, P. Evaluation of promoters and ribosome binding sites for biotechnological applications in the unicellular cyanobacterium Synechocystis sp. PCC 6803. Sci. Rep. 2016, 6, 1-12. [CrossRef]

107. Zhou, J.; Zhu, T.; Cai, Z.; Li, Y. From cyanochemicals to cyanofactories: A review and perspective. Microb. Cell Fact. 2016, 15, 1-9. [CrossRef] [PubMed]

108. Gründel, M.; Scheunemann, R.; Lockau, W.; Zilliges, Y. Impaired glycogen synthesis causes metabolic overflow reactions and affects stress responses in the cyanobacterium Synechocystis sp. PCC 6803. Microbiology 2012, 158, 3032-3043. [CrossRef]

109. Srivastava, A.; Brilisauer, K.; Rai, A.K.; Ballal, A.; Forchhammer, K.; Tripathi, A.K. Down-regulation of the alternative sigma factor SIGJ confers a photoprotective phenotype to Anabaena PCC 7120. Plant Cell Physiol. 2017, 58, 287-297. [CrossRef]

110. Tailor, V.; Ballal, A. Novel molecular insights into the function and the antioxidative stress response of a Peroxiredoxin Q protein from cyanobacteria. Free Radic. Biol. Med. 2017, 106, 278-287. [CrossRef]

111. Frizzi, A.; Huang, S. Tapping RNA silencing pathways for plant biotechnology. Plant Biotechnol. J. 2010, 8, 655-677. [CrossRef]

112. Kanno, M.; Carroll, A.L.; Atsumi, S. Global metabolic rewiring for improved $\mathrm{CO}_{2}$ fixation and chemical production in cyanobacteria. Nat. Commun. 2017, 8, 1-11. [CrossRef]

113. Koch, M.; Bruckmoser, J.; Scholl, J.; Hauf, W.; Rieger, B.; Forchhammer, K. Maximizing PHB content in Synechocystis sp. PCC 6803: Development of a new photosynthetic overproduction strain. bioRxiv 2020. [CrossRef]

114. Watzer, B.; Engelbrecht, A.; Hauf, W.; Stahl, M.; Maldener, I.; Forchhammer, K. Metabolic pathway engineering using the central signal processor PII. Microb. Cell Fact. 2015, 14, 1-12. [CrossRef] [PubMed]

Publisher's Note: MDPI stays neutral with regard to jurisdictional claims in published maps and institutional affiliations.

(C) 2020 by the authors. Licensee MDPI, Basel, Switzerland. This article is an open access article distributed under the terms and conditions of the Creative Commons Attribution (CC BY) license (http://creativecommons.org/licenses/by/4.0/). 